Int. J. Electrochem. Sci., 13 (2018) 10848 - 10858

\title{
Hydrogen Production Using Electrodeposited Ni and Ni/Co on Carbon Paper as Cathode Catalyst in Microbial Electrolysis Cells
}

Yuxue Wang, Yu Zhao*, Ailian Wu*, Zhishuai Dong, Jia Li and Junwen Wang

College of Chemistry and Chemical Engineering, Taiyuan University of Technology, Taiyuan, Shanxi, P. R. China, 030024

*E-mail: zhaoyu@,tyut.edu.cn, wuailian@tyut.edu.cn

doi: $10.20964 / 2018.11 .71$

Received: 29 June 2018 / Accepted: 9 September 2018 / Published: 1 October 2018

Microbial electrolysis cells (MECs) utilize microorganisms to decompose organic matter in wastewater and produce hydrogen at the cathode. Thus, a low-cost and highly active cathode material is of great important in such system. In this study, electrodeposited $\mathrm{Ni}, \mathrm{Co}$, and $\mathrm{Ni} / \mathrm{Co}$ on carbon paper (CP) were prepared as cathode to replace platinum. At an applied voltage of $0.7 \mathrm{~V}$, the Ni MEC cathode produced most gas of $11.40 \mathrm{~mL}$ at current density of $15.31 \mathrm{~A} \mathrm{~m}^{-2}$, which was $73.24 \%$ higher than that of bare $\mathrm{CP}$ electrode $(3.05 \mathrm{~mL})$. Linear sweep voltammetry and Cyclic voltammetry measurements showed that the hydrogen evolution performance of the $\mathrm{Ni}$ cathode was significantly better than $\mathrm{Co}$ and $\mathrm{Ni} / \mathrm{Co}$ cathodes. The tafel plots proved that the hydrogen evolution overpotential of Ni cathode $(59.89 \mathrm{mV}$ decade $^{-}$) was lower than that of bare $\mathrm{CP}$ electrode (99.22 $\mathrm{mV}$ decade $^{-}$). Owing to the improved current density, hydrogen recovery rate and low hydrogen evolution overpotential, the developed electrodeposited $\mathrm{Ni}$ on $\mathrm{CP}$ materials possessed much higher catalytic activity than bare $\mathrm{CP}$. Thus, electrodeposited $\mathrm{Ni}$ on $\mathrm{CP}$ are promising electrocatalysts for hydrogen evolution reaction and low-cost cathode materials in MECs.

Keywords: Microbial electrolysis cells; electrodeposited Ni/Co; carbon paper; hydrogen evolution reaction.

\section{FULL TEXT}

(C) 2018 The Authors. Published by ESG (www.electrochemsci.org). This article is an open access article distributed under the terms and conditions of the Creative Commons Attribution license (http://creativecommons.org/licenses/by/4.0/). 